\title{
HUMAN SECURITY, MARGINALITY AND PRECARIOUSNESS IN SOUTHEAST ASIA
}

\author{
Paul J. Carnegie* \\ Institute of Asian Studies, Universiti Brunei Darussalam, \\ Jalan Tungku Link, Gadong BE1410, Brunei \\ E-mail: paul.carnegie@ubd.edu.bn \\ Victor T. King ${ }^{* *}$ \\ Institute of Asian Studies, Universiti Brunei Darussalam, \\ Jalan Tungku Link, Gadong BE1410, Brunei \\ E-mail: victor.king@ubd.edu.bn \\ Magne Knudsen ${ }^{* * *}$ \\ Department of Sociology and Anthropology, Universiti Brunei Darussalam, \\ Jalan Tungku Link, Gadong BE1410, Brunei \\ E-mail: magne.knudsen@ubd.edu.bn
}

Published online: 15 January 2021

To cite this article: Carnegie, P. J., King, V. T. and Knudsen, M. 2021. Human security, marginality and precariousness in Southeast Asia. International Journal of Asia Pacific Studies 17 (1): 1-28. https://doi.org/10.21315/ijaps2021.17.1.1

To link to this article: https://doi.org/10.21315/ijaps2021.17.1.1

\begin{abstract}
Besides the more obvious threats and impediments to human security posed by conflict or natural disaster, a central problem in examining and addressing multiple insecurities in Southeast Asia is at what level. Each country confronts a different context of human security and faces a host of intersecting circumstances that render situational day-to-day forms of precariousness difficult to recognise and interpret. How then are we to proceed? This article considers a range of social science concepts and approaches (which have not been brought together in this form before) and their utility for investigating human security in the region. It argues that more disaggregated and grounded perspectives can open the way for human security to gain fuller analytical purchase on contemporary marginality and precariousness in Southeast Asia.
\end{abstract}

Keywords: Human security, Southeast Asia, marginality, precariousness, UNDP 


\section{INTRODUCTION ${ }^{1}$}

Human security came to the attention of the international community in the mid-1990s with the release of the United Nations Development Programme (UNDP)'s Human Development Report (1994). A primary observation of the UNDP report was that many nation-states continued to privilege military expenditure over and above the human development and welfare priorities of their populations (Roberts 2007). While far from moribund, the state-centric security and military paradigm was admonished for being increasingly at odds with the challenges posed by contemporary sources of conflict and insecurity in a globalising world (Kaldor 1999; ul Haq 1995). This was attributed to the fact that "the concept of security has for too long been interpreted narrowly: as security of territory from external aggression, or as protection of national interests in foreign policy... it has been related to nation-states more than people" (UNDP 1994: 22-23).

Broadening and deepening the meaning and application of security in non-military terms was proposed as a crucial first step in trying to address this issue (Caballero-Anthony 2004: 155-189). It was a normative attempt to shift the discourse and practice of security. The greater focus on individual freedom and development underscored recognition that economic, food, health, environmental, personal (in relation to crime and violence), community (particularly in relation to inter-ethnic issues and minority group rights) and political (with reference to basic human rights) security are interdependent and mutually supportive of long-term international security, sustainable development and poverty reduction in the 21 st century (Commission on Human Security 2003; UNDP 2005).

Despite the normative appeal of human security, trying to recalibrate the scope and remit of security as both policy and practice is a bold endeavour. The ability to encapsulate a wide array of concerns from climate change, environmental degradation, irregular migration and displacement, transnational crime and trafficking, sexual, ethnic and youth violence to unbridled urbanisation and a lack of access to drinkable water and sanitation and then link them to a single concept risks being as difficult to focus as it is to implement. There is no one theory or conceptual framework which enables us to capture the complexity of human security.

As such, the attempt to expand security beyond the level of international relations between nation-states and their traditional security concerns has been met with much definitional contestation and criticism over purpose and 
scope (Chandler 2008: 427-439; Duffield and Waddell 2006: 1-23; Krause 2004; Paris 2001: 87-102). For Barry Buzan (2004: 369-370), the concept is too idealistic with limited analytical utility for prioritising and apportioning valuable resources. Roland Paris (2004: 370-372) dismisses its inscrutable character as too open-ended and imprecise for practical application. As Yuen Foong Khong (2001: 231-236) crushingly surmises, trying to prioritise everything means nothing is prioritised. Others have further argued that the adoption of human security discourse by some states allows them to mask an entrenchment of elite interests (Chandler and Hynek 2011).

Evidently, a tension exists between the ways in which local, community and individual level insecurities are not only recognised but understood and the transferability of the human security agenda to particular settings. In this article, we argue that the study of human security in Southeast Asia (which tends to be dominated by the disciplinary concerns of international relations, development and security studies) should engage a fuller range of multidisciplinary social science lenses. The concepts and approaches they provide can assist in recognising and developing our understanding of the underlying conditioning factors and interests (the politics of precariousness) embedded within the day-to-day human insecurities across Southeast Asia.

Whilst we should not lose sight of broader perspectives, they tend to underplay the diverse realities of human insecurities on the ground and aggregate individuals and communities within narrowly constructed framings of "risk" and "vulnerability" (O'Neill 2014; Rebotier 2012). This is problematic. It creates an essentialised discursive appearance that understates the contextual range of precariousness faced by marginalised individuals and communities. In the process, localised issues of power, politics and inequality are often overlooked.

If each country confronts a different context of human security and faces a set of specific challenges, how are we to proceed? Histories, geographies, cultures and ethnicities differ, configurations of politico-business elites and patterns of civil-military relations vary, as do the respective positions within the international system of power and privilege. Southeast Asia is bearing witness to profound changes in patterns and types of work, labour relations, rapid urbanisation, high levels of social inequality, accelerating environmental degradation, reconfiguring social and political cleavages and issues around human rights. They permeate the social structures of the region's countries in different ways. Addressing the impacts of such transformations requires more than general approaches and generic responses to predetermined problems. 
Here we contend that disaggregated and grounded social science perspectives can help identify underlying conditions embedded in day-today lived experience more effectively. From our standpoint, it is not possible to encapsulate the range of issues confronting countries, communities and individuals of Southeast Asia within a neat conceptual framework of human security. Conceptually, human security is only a point of entry from which to interpret and understand the politics of precariousness experienced by different peoples and communities. As such, it should be afforded a variable understanding, based on variable contexts, rather than adopted as a broad catch-all category.

To build the argument, we place a set of interrelated social science scholarship, not previously brought together in this form and for this purpose, in dialogue with each other. In doing so, we underscore the utility of the different perspectives and angles of vision afforded by scholars as varied as Karl Marx, Émile Durkheim, Zygmunt Bauman, Anthony Giddens, Mary Douglas, Olivia Harris, James C. Scott and Edward P. Thompson. In their respective ways, they not only conceptualise and address issues of risk, insecurity and marginality, but many of them were marginal or saw themselves as marginal from mainstream society. They speak powerfully to the varying effects on the human condition of industrialisation, urbanisation, marginalisation, social exclusion, inequality and environmental degradation. As such, the choice of scholars informs the structure of our investigation. We thread each of them in turn through substantive thematic and country specific sub-sections to animate the salience of their discursive interventions. From which emerges an interconnected collage of complimentary concepts and approaches, closely integrated into our narrative, that encapsulates more fully the subtleties, nuances and impacts of the transformations people and communities are living through in the region.

Taken as a composite lens, their work allows us to see beyond general appearances and gain a greater appreciation of situational power, politics and inequality configuring the range of marginality and precariousness in the region. However, import from the insights should not be read as definitive templates but rather indicative of a path ahead; one that re-situates human security, not as a catch-all category but a point of entry for interpreting and understanding the politics of precariousness embedded within human insecurities in Southeast Asia. 


\section{HUMAN INSECURITIES IN SOUTHEAST ASIA}

The total population of Southeast Asia is forecast to grow from around 640 million to over 800 million by 2050 (United Nations 2019). Climate change is set to pose a profound threat to the livelihoods, security and well-being of many people in the region. If the seas of Southeast Asia warm at a rate even below current conservative estimates, this will have a profound impact on coral reefs, mangroves and low-lying coastal and delta basin areas (Prakash 2018; Hijioka et al. 2014). It will bring shifts in monsoonal precipitation patterns and the frequency and intensity of typhoons. The overall prognosis is deeply troubling with the prospect of rising sea levels, forced migrations, degradation of aquatic ecosystems and declining fish stocks from ocean temperature rises and plastic pollution, the contamination of freshwater through saltwater inundation, land degradation and loss (impacting on food security, livelihoods and cultural life), and an increasing incidence of waterborne and vector-borne diseases such as dengue, chikungunya, malaria and typhoid. Dealing with the attendant host of intersecting human insecurities of such a future is a pressing concern for the region.

Those living in precarious circumstances across Southeast Asia may have different histories, geographies and face varying socio-economic, political and cultural realities, but they also convey common messages. Whether it be the marginalised communities of Penan, Iban and Orang Asli in Malaysia or Karen on the Thai-Myanmar border, upland shifting cultivators in the southern Philippines, or informal coastal dwellers and migrants who traverse borders, or street children in Jakarta, Bangkok and Manila, they have rights as human-beings to protection and support in the conduct of their daily lives (Carnegie et al. 2016). Recognition of these rights is often in short supply.

Their protection is more encompassing than just a commitment to individual freedoms or short-term safeguards against armed conflict or natural disaster. It involves a greater integration of political, social, environmental, economic, military and cultural systems in the service of opportunities and prospects of individuals and communities over time. Yet, they discursively, and in some cases, literally disappear to make way for an overarching sense of nation-state development. Governments tend to assign them a low priority or quite simply do not have the capacity, the political will or interest to help them. 
In many countries of the region, political elites wish to secure national borders and promote agricultural modernisation, large-scale commercial plantations and aquaculture (Carnegie et al. 2016). The expansion of agribusiness can improve export trade but at the same time, rural areas are subject to the pervasive effects of land grabbing that brings with it environmental degradation and complex configurations of poverty and social inequality. Securing borders can reinforce national security and requires punitive action and sanctions against those who do not conform but the preoccupation with maintaining borders does not necessarily facilitate human security. It can often force many sea-mobile populations into vulnerable and precarious predicaments.

As Rob Nixon (2009: 62-80) notes, the nation-state is not only sustained by the production of "imagined communities" but the active production of "unimagined communities." The latter refers to those internal communities that do not fit or inconvenience resource exploitation and national development plans. Their physical displacement (in order to make way for certain types of development) is predicated on a prior imaginative and temporal evacuation. They are selectively and administratively "unimagined" by the highly partial discourses and practices of putative national assent. It is not just the shadows cast from monumental infrastructure developments that render them figuratively and, in some cases, literally invisible, but there is simultaneously a decoupling of them in discourse and practice from the collective memory of nation-state building. To survive, they are forced to make their own way and develop their own creative solutions to address insecurities. The state does not support them and indeed may exploit them in a range of contexts. Decisions of political leaders, taken, as they argue, in the interests of the nation-state, often cut across and compromise what is needed to ensure their local-level collective "security" and well-being.

Having said this, it is hardly surprising that national-level policymaking in complex societies will invariably have an adverse effect on the interests and security of some segment of those societies. The compromise can take many forms. A need to cut public deficits frequently leads to a reduction in the resources provided for law and order. As a result, fear and anxiety can increase the crime levels and the threat to individual security and well-being. The pressure from global financial institutions to prioritise interest payments on national debts gives rise to reductions in public funding of health services or education and concomitant increases in charges and fees. This makes it difficult for families to ensure that their children will have access to the 
health services and education necessary to ensure their future occupational and economic security.

Given such dilemmas, various scholars working on Southeast Asia have supported the efficacy of human security for identifying a lack of human development opportunities and welfare provision for impoverished communities across the region. And whilst ASEAN has endorsed a peopleoriented human security agenda, ${ }^{2}$ these scholars have rightly pointed out that ruling political elites in many Southeast Asian countries are often more preoccupied with attracting foreign direct investment, promoting largescale commercial plantations and initiating vast infrastructure projects at the expense of individual and community well-being (Acharya 2001; CaballeroAnthony 2018; Caballero-Anthony and Cook 2013; Howe 2013; Nishikawa 2010).

Their work has been significant in heightening awareness of threats and impediments to human security in Southeast Asia, but less clear and convincing in identifying the diverse politics of precariousness and marginality embedded in daily-lived human insecurities. As we argue here, there is no neat framework of human security to encapsulate the range of contemporary issues confronting individuals and communities in Southeast Asia. Instead, in the following sections, we draw together work on marginality from the social sciences that can assist in recognising and developing our understanding of the multiple conditioning factors and interests (the politics of precariousness) embedded within human insecurities across the region.

\section{MARX, DURKHEIM AND DISASSOCIATION}

To begin, we consider the work of Marx and Durkheim for situating and recognising the profound impact rapidly changing circumstances can have on the human condition. For Karl Marx (1844/1968), alienation was a loss of connection between what we produce and why we are producing it. We experience a loss of control over our working lives, identities and relationships. For those who experience insecurity, or perceive themselves to be living in precarious circumstances, this sense that they lack control over decisions about their own life is often high. They experience risk and uncertainty in the exercise of their everyday routine and may feel they have little say in the way in which their community, and at a higher level, the nation-state is run. As lives become more disrupted by rapid economic and socio-cultural 
transformations, people can experience a sense of separation and loss about the norms and values that previously governed everyday relationships (Wertheim 1974). This may develop into an inability to identify with and acknowledge the dominant norms of wider society and further deepen feelings of isolation, disaffection and marginalisation.

Marx draws our attention to the vulnerability and uncertainty that permeate changing patterns of work and labour. This has relevance in thinking about the impact many contemporary and increasingly temporary employment conditions have on individuals and communities in Southeast Asia. As youth unemployment rates go up in parts of the region, school-leavers are hardpressed to find gainful employment. If they do, they are confronted with low salaries, mismanagement and a lack of opportunities for career advancement (International Labour Organization [ILO] 2017). Gaining an awareness of mismatched expectations, hamstrung employment realities and the pressure to seek out alternative income alerts us to the challenges individuals and communities face. There is an increased risk of disassociation from the dominant values and ideals of the developmental state in which they live.

It was Émile Durkheim (1893/1977) who identified this tendency symptomatically as anomie. In a time of rapid modernisation, urbanisation and individualisation across Southeast Asia, social bonds are under increasing stress. As disparities between expectations, desires and behaviour and the reality of situations widen, so too the anomie. For Durkheim (1897/1951), such situations can lead individuals to experience normlessness and disconnection. In extremis, it can lead to the taking of one's own life.

\section{Suicides in Southeast Asia}

Marx and Durkheim show us that a lack of identification with the dominant values and ideals of the state in which people live can create a range of sociopsychological problems. Sociologically, we can point to several key stressors including unemployment, pre-existing mental health conditions, financial problems, substance abuse, changing socio-cultural expectations, familial breakdown, bullying and various forms of violence and abuse, especially sexual- and gender-based. These stressors form an interlinked aspect of contemporary marginalisation and precariousness wrought by rapid economic and socio-cultural change. It draws our attention to one of the region's silent predicaments: suicide. 
The World Health Organization (WHO) provides figures of close to 800,000 deaths globally every year due to suicide with an estimated 40 percent in Southeast Asia (WHO 2020a, 2020b; and see WHO 2014). Senior citizens between the ages of 60 and 64 also have a high suicide ratio of 10:100,000, primarily due to abandonment by their families. According to Thailand's Mental Health Department Director-General, Boonreung Traireungworarat, six people attempt suicide every hour in Thailand. That is about 53,000 annually. And whilst most ASEAN countries have de-criminalised suicide and suicide attempts, it is still considered an offence in Malaysia and Brunei Darussalam, a situation that prevents many from seeking help. In Cambodia, data identify two groups most likely to attempt suicide: adolescents and women with histories of trauma and abuse (WHO 2020a, 2020b; and see WHO 2014).

\section{BAUMAN, GIDDENS AND MODERNITY'S DISCONTENTS}

Many writers and scholars have taken up the concerns identified by Marx and Durkheim and developed them in relation to late modernity and globalisation (Bauman 2000, 2003, 2005, 2006a, 2006b, 2011; Beck 1992; Bhide and Stevenson 1992; Endres and Six-Hohenbalken 2014; Giddens 1990, 1991; Harvey 2006; Heine and Thakur 2011; Standing 2016; Stiglitz 2002; Watson and Moran 2005; Zinn 2008). Zygmunt Bauman and Anthony Giddens in particular provide valuable insight on contemporary human insecurities. For Bauman (2005), a major task of modernity has been to remove unknowns and uncertainties; to make order and to allocate people a place in the division of labour, to rationalise, bureaucratise, categorise and address personal insecurities, but this process of order-making is never complete. Significantly, for Bauman $(2005 ; 2011)$ and Giddens $(1990 ; 1991)$, some people are never administered and incorporated in this way. They remain "strangers," "outsiders" or "others" and can become identified as people to be feared, coerced and unimagined.

Moreover, in late modernity, individuals may be free to choose but simultaneously uncertainties, risk and emotional stress have become ever more diffuse, and therefore the choices rendered more complex (Bauman 2006b; Hutton and Giddens 2000). These are salient points for developing our awareness of both the experience and perception of uncertainty among various 
social and cultural groups (King 2016: 25-42). In a world of consumers (or those who can afford to consume), those who live in sink estates, squatter settlements, banlieues, slums or favelas are increasingly closed off and marginalised. They are unemployed, spatially and socially segregated, involved in crime, are feared; they are "outsiders" living in a world of insecurity and uncertainty themselves; a condition they simultaneously internalise and project externally (Bauman 2006a; Hutton and Giddens 2000; Standing 2011). Consequently, those who can afford to consume, increasingly live in walled and gated communities, employ private security with surveillance technology, alarms and guard dogs.

\section{Private Security in Southeast Asia}

The reality of the uncertain conditions and exclusionary situations identified by Bauman and Giddens is reflected in the growth of security services in Southeast Asia. The industry in the Asia Pacific region (excluding Japan) was estimated at roughly USD28 billion in 2011 (HSBC 2012). With over 100,000 vessels transiting the Straits of Malacca carrying one-third of the world's traded goods each year, anti-piracy protection for merchant vessels and security for ports and offshore oil/gas platforms are in high demand (Liss 2014; ChinaPower 2017).

Private security companies in the region have increased exponentially over the last decade. Malaysian security service companies alone have grown from 350 in the 1990s to now more than 750 (Persatuan Perkhidmatan Kawalan Keselamatan [PPKKM] 2016). These companies provide everything from cash-in-transit protection to safeguarding shopping malls, condominiums, embassies, banks, hospitals, playparks and restaurants. Interestingly, this wide variety of services were, in the past, largely the responsibility of government agencies. Much grey area permeates the industry which is linked to the fact that gangs, militias and "protection" have long been a clandestine feature of social and political life in the region (Wilson 2012: 288-301). The insecurity generated by uncertainty and social exclusion is now a business opportunity. If you walk around the sprawling capitals of Jakarta, Kuala Lumpur, Bangkok or Manila, there is an immediate sense of the burgeoning private security sector. The market demand is partly driven by heightened feelings of perceived insecurity among various social groups and business owners. But as Bauman and Giddens point out, the frailty of human bonds and fears over personal security in late or liquid modernity are precursors to the situations we seek to manage but rarely avoid. 


\section{DOUGLAS, HARRIS AND WAYS OF LIFE}

If Bauman and Giddens draw our attention to the impacts of uncertainty and social exclusion in late modernity, then Mary Douglas and Olivia Harris advance our understanding of group identity and its relationship to risk in the face of perceived threats and insecurities. How do we decide upon what is potentially dangerous or harmful and what is not? Just as our experience of uncertainty is coincidental to our construction of it, so too with risk. If we accept that perceptions of risk are socially constructed, then they represent different evaluations. In other words, there are different estimates of life chances within different institutional and historical contexts, and with reference to sets of cultural values and ways of life (Douglas and Wildavsky 1982).

For Douglas (1992), perceptions of risk represent different evaluations and estimates of life chances within different institutional and historical contexts. An appreciation of "ways of life" is important in order to grasp the sets of values being referenced. Different permutations of social organisation endow people with perceptions that serve to strengthen the very institutional context within which they are embedded. This can breed an aversion to subversive or marginal behaviour and a tendency to focus resentment and blame on those who are perceived to be different, defy authority and institutions, and live on the edge of what is defined as "society" (Douglas and Wildavsky 1982). Although not without explanatory limitations, this provides a frame to help explain people's outlook on risk and uncertainty, and the apportioning of blame if things go wrong (Boholm 1996: 64-84).

In times of rapid socio-economic change, cultural ways of life and what levels of uncertainty people are prepared to tolerate and how they organise themselves to cope with them play a key explanatory role. This has major relevance in Southeast Asia where customary practices and traditional beliefs remain prevalent and co-exist with more contemporary ways of life. Adherence to and suspicion of certain beliefs and practices also intersect with a wide array of social deprivation issues and uneven economic development. Varying degrees of public health awareness and differing levels of national cohesion amongst diverse ethnocultural groups mediate the ways individuals and communities deal with risk and uncertainty and where they apportion blame for their predicaments.

What bears further on this theme are the ways in which identities and ethnicities are constructed or crystallise. As Olivia Harris (1996: 1-16) emphasises, in response to heightened levels of risk and uncertainty, social 
groups "defend continuity, and their rights to claim and express particular links with the past." Often, they do so in the face of perceived threats and insecurities brought about by rapid change, and the domination of some by others (Carnegie 2015: 15-26; Kahn 1998). This can take the form of opposition to policies and practices of the nation-state or large-scale commercial activities.

\section{ACQUISITION AND DISPOSSESSION IN SOUTHEAST ASIA}

The framings of Douglas (1992) and Harris (1996) provide a further reference point for interpreting the rivalries and tensions simmering beneath a rapidly transforming region. They both speak to the ways in which group identities form and respond in the face of threat and insecurity. It helps us explain why community survival and renewed claims to ethnicity are so keenly felt in many parts of Southeast Asia especially over the acquisition, dispossession and degradation of customary land. The region has become a global hotspot for disputes over the apportioning of land to intensive, industrial scale agrobusiness such as oil palm, sugarcane, wheat, soybean and maize. It is a sensitive and divisive matter which is hardly surprising given that farming is the main source of income for many people: 54 percent in Cambodia, 44 percent in Vietnam, 33 percent in Indonesia, 32 percent in Thailand, 29 percent in the Philippines, and 12 percent in Malaysia (Roughneen 2017).

Forced evictions, land grabbing or coercive incorporation into the global agro-food-feed-fuel complex sets in motion many of these disputes (Borras and Franco 2011). Out of 51 major land disputes across the region, 45 remain unresolved (TMP Systems 2017). Border regions inhabited by ethnic minorities often overlap with special economic zones created by governments that offer tax breaks and incentives to attract investment. Local officials in peripheral or border areas are often susceptible to "persuasion" and the rule of law less tenable. Extensive decentralisation reforms in Indonesia have, in certain cases, created situations where there are contradictory laws at national and local levels that confuse and complicate matters further. Although sometimes frail, bonds of cultural identity, connection with the past, celebration of tradition, and the mutual support which underpin claims for continuity, are sometimes all that can be mustered to counter the feelings of dislocation and insecurity generated by such situations. 


\section{On the Land: Malaysia and Indonesia}

This deeply problematic issue is evidenced in the tension between ensuring environmental, food and community security, on the one hand, and politically connected companies, on the other, acting with a perceived sense of impunity when it comes to native customary land tenure (McCarthy 2010: 821-850). It is especially the case where pre-existing claims to land are not formally recognised by national law. Local communities may have inhabited an area for millennia as "eco-system" communities and it "belongs" to them and they to it; in other words, they have "rights" in it and over it, but they do not own it in the Lockean sense of private property (Nixon 2009: 77-78). The aforementioned lack of clarity on land tenure and insidious levels of corruption have led to large scale "land grabs" on the part of avaricious logging and mining interests and the alienation of extensive tracts of customary land. This has resulted in food insecurity and the collapse of long-established food systems among many indigenous populations. Local opposition to these situations is driven by combinations of displacement, environmental damage, reduced access to basic resources and inappropriate compensation.

In a study of the Orang Asli (indigenous people) in the Malaysian states of Kelantan, Pahang and Perak, it was found that 80 percent of those in the nine survey villages were plagued by food insecurity as a result of the failure of agriculture, hunting and gathering generated by land dispossession, the depletion of forest resources, the length of time consumed in seeking scarce resources, the lack of continuity and cleanliness of natural water supplies, forced resettlement and the lack of knowledge among the younger generation of traditional food systems (Law et al. 2018: 141-142). These pressures fell particularly on those who were already vulnerable: low-income households, dependent children and the elderly. Moreover, the vulnerable were members of Orang Asli communities (numbering some 180,000 in 2013) which "still live on the fringes of Malaysian society cut off from social services, poorly educated and making a meager living" (Endicott and Dentan 2004: 24).

A similar situation is found among the indigenous people of Sarawak and Sabah in Malaysian Borneo where large swathes of primary growth forest have been lost (Straumann 2014). One of the tragic cases is that of the Penan, former hunting-gathering populations of the interior rainforests, though many upriver farming communities such as the Iban were also caught up in the pressures exerted by powerful external political and economic forces claiming that their actions were guided by the need to "modernise" less developed rural 
communities (Survival International 2013; Human Rights Now 2016). The Penan struggle against government-backed commercial logging companies made headlines, nationally and internationally. Not only were they in search of the recognition of their rights to secure their livelihoods (economic and food security) from the surrounding forests and their ancestral lands, but also engaged in a struggle over their identity and the cultural meanings they attached to their community security; their lives and everyday practices (Cooke 1999). These actions were ultimately to make little difference. They were caught in a paradoxical situation, subject to government objectives to incorporate them into the Malaysian nation-state, but as a result being rendered increasingly marginal in that state (King 1993).

Disruptive resource development policies and practices send "project affected people" ricocheting back and forth from desperate situations. Displacement wrought by large-scale dam construction, agro-business, logging and mining operations amplifies a sense of loss and feelings of marginality and resentment (Chu 2017). Communities and individuals become casualties of what has been termed euphemistically the "resource law of inverse proximity." That is to say, communities who are closest to a resource being "developed" often benefit the least (Nixon 2009: 78).

The perspectives on group identity formation offered by Douglas and Harris also have relevance in understanding the ways in which tensions stoked by patterns of internal migration can spill over into conflict in particular locales. During the Suharto era in Indonesia there were extensive and controversial programmes of transmigration (transmigrasi). Ostensibly, they were promoted as a way to deal with overcrowding and poverty. Opportunities were provided to relocate to resource rich but more sparsely populated outer islands. By the 1990 s, more than 3.6 million people had been resettled to outer islands, where they received a government allocation of land for cultivation, housing and a subsistence package for relocating (Badan Pusat Statistik 2012).

The scale of transmigration did, however, create tensions between local indigenous populations (putra daerah - son of the soil) and pendatang (migratory newcomers) over land use and access to subsidies. The large influxes of newcomers amplified fears and animosity among local populations over what they perceived as state-sanctioned marginalisation and creeping cultural homogenisation (Wessel and Wimhofer 2001). This led to a hardening of ethnoreligious differentiation and allegiances. In certain provinces, tensions have periodically spilled over into communal violence (Bertrand 2004; Carnegie 2017). Although typically framed as ethnoreligious violence, 
it should be noted that internal migrants often make convenient scapegoats for other underlying political, economic, environmental and scarcity issues (Davidson 2003). They are easily "othered" as the unwitting proxies to often disruptive state and commercial practices.

\section{By the Coast: Philippines}

When thinking about issues of dislocation and insecurity, there is also an intimate link between broader processes of agrarian transition and politicaleconomic change in coastal Southeast Asia. With generally low barriers to entry, small-scale fishing absorbed many rural poor during the twentieth century. As Firth (1966: 65-67) demonstrated in his ground-breaking analysis Malay Fishermen, it was primarily land poor and landless groups who turned to fishing as a main livelihood source and settled close to the coastlines.

Philippine coastal settlements grew rapidly during the latter part of the century (Eder 2008: 33; Knudsen 2009: 32-60). Many settled on unclaimed lands with public domain status along the shorelines (Bankoff 1999; Calvan 2015). Yet, coastal land tenure insecurity is often given scant regard. In littoral spaces, state-defined property regimes tend to be ambiguous, with contradictory and overlapping laws. Low-income groups living near the sea have struggled to secure formal title or legal lease to the land they inhabit (Austin 2007: 2). It is simply too expensive for them to buy and many find the legal-bureaucratic process of "formalising" their land claims overly complicated and costly.

With the coastlines of Southeast Asia undergoing rapid change, the above situations take on worrying dimensions for those most affected. Investments in coastal tourism, high-end real estate, coastal roads, ports and special economic zones are booming along with the expropriation and degradation of mangroves, reef systems and traditional fishing waters. An estimated 50 percent of the Philippine mangroves have disappeared. Healthy, productive coral reefs are few and far between. The human cost of these transformations for the millions of people who dwell informally near the shorelines is high. They face intensified displacement pressures but, with a few notable exceptions, the implications of territorial enclosure and "coastal grabbing" has received little in the way of attention, not only in the academic community, but also from non-governmental organisations (NGOs) and multilateral institutions (Bavinck et al. 2017; Fabinyi 2010; Knudsen 2012; Uson 2017). 
Industrial fishing fleets, large-scale aquaculture facilities, coastal tourism and no-fish conservation zones undermine small-scale fishers' ability to access and benefit from fisheries resources. "Blue revolution," "blue economy" or "blue growth" initiatives, as well as new coastal and ocean governance regimes, frame coasts and oceans as a new kind of economic frontier (Silver et al. 2015). Significantly, despite having serious implications for small-scale fisheries and coastal livelihoods, initiatives are mainly informed by economic and ecological research, and not by the findings of social science literature. The overarching assumption is that coastal tourism and aquaculture will provide adequate alternative work and improved income opportunities for subsistence fishing communities, but this does not really hold up to scrutiny (Kelly 1996; Fabinyi 2010; 2018). Large scale developments often reproduce entrenched inequalities and create new vulnerabilities for disadvantaged and marginalised coastal dwellers. As Cohen et al. (2019: 1) argue, rather than "fixing" the problems faced by many small-scale fisheries, the livelihoods they sustain are instead "being subtly and overtly squeezed for geographic, political and economic space by larger-scale economic and environmental conservation interests."

\section{SCOTT AND THOMPSON ON THE MARGINS}

If Douglas and Harris advance our understanding of group identity in the face of perceived threats and insecurities, then the work of James C. Scott and E. P. Thompson alert us to the impact of a breakdown in trust and respect for those living on the margins. As highlighted, significant populations in Southeast Asia are engaged in various forms of farming and fishing but the spectre of displacement and dispute loom large. For Scott $(1977 ; 1985)$, social organisation in many agrarian and fishing communities across the region and the ways in which they evaluate the behaviour of others are oriented to the need to secure an adequate level of subsistence (the "subsistence ethic"). A primary concern for them is with the security of supplies of basic foodstuffs and other essential needs (shelter, support and mutual reciprocity) (King 1978; Götz 2015). In this context, local elites are seen as a source of charitable donations and other gifts or provisions. Scott and his co-researcher Benedict J. Kerkvliet focused on the character and quality of these patronclient relations and the consequences of their breakdown or breach for peasant security in Southeast Asia (Scott and Kerkvliet 1977). In short, they draw attention to the contextual bonds of trust and respect. 
In this regard, both Scott and Kerkvliet owe an intellectual debt to pivotal works in social history by E. P. Thompson (1963/2013; 1971: 76136). In a different setting, Thompson pointed out that the fabric of this type of paternalistic "moral ordering" can unravel with the intervention of impersonal market relations, capital and profit (in other words, modernity). Thompson sought not simply to re-write history from the perspective of the downtrodden (history from below), but to capture the values, perspectives and culture of those living at the margins and rescue them "from the enormous condescension of posterity" (Thompson 1963: 12-13, repr. 2013).

The "moral economy" as it was originally formulated by Thompson $(1963 / 2013 ; 1971)$ and then developed by Scott $(1977)$ in relation to peasant rebellion in a Southeast Asian context has been well established in empirical terms. When respect for the subsistence needs of the rural poor, their networks of mutual support and sense of give-and-take fairness is eroded, the likelihood of resistance and protest increases (Kerkvliet 1977; King 1980; 1981; Popkin 1979). It is a salutary caution for forms of development that ignore the needs and cultural mores of communities they are supposed to benefit.

Scott's (1985) "weapons of the weak" demonstrated further how those under pressure and threat react. Having said this, they often do so reluctantly and attempt to explore and exhaust other ways of addressing and persuading those in power. Significantly, the prospect of losing face, the risk to dignity and experiencing acute embarrassment in relationships which are becoming increasingly tense tend to work against more forthright approaches to negotiation and protest. Rutten (2007: 38), in an examination of how "shame" might inhibit activism in Philippine labour relations, identifies an "emotional dynamic of shame," namely the fear of humiliation in not behaving properly.

For marginal and precarious individuals and communities in Southeast Asia, climate-induced migrations and threats to water and food security on future livelihoods will bring into sharp relief the starkness of their situations. If we are to give recognition to the values, perspectives and culture of those living at the margins, and those who had been left out of history, then paying attention to contextual bonds of trust and respect is an important step.

\section{Disaster Risk and Resilience for Whom in Southeast Asia?}

The work of both Scott and Thompson point us towards the complexities of the encounters between those who control and represent the nation-state and those without power and influence whose security, safety and well-being are 
ostensibly the responsibility of governing elites. There is often a lack of trust or respect for the policies and actions of the state due to the adverse impact they have on at-risk communities.

Although typhoons, storm-surges and sea-level rise do pose major risks to the life and livelihood of those dwelling along shorelines and demand action, these highly visible symptomatic "disasters" often serve to mask the logics of other more insidious transformations. The effects of the imposition of no-build zones in post-disaster reconstruction are putting millions of coastal dwellers at risk. After super-typhoon Haiyan in Central Philippines and Thailand, and Indonesia after the 2004 Indian Ocean tsunami, governments in all three countries established coastal setback zones and launched relocation projects (Iuchi and Maly 2016; Uson 2017; Yee 2017). In the intervening years, instead of creating disaster-resilient communities, many of these housing projects (that were aimed at moving "vulnerable people" to "safe areas") ended up exacerbating pre-existing problems of land tenure and livelihood insecurity for disadvantaged coastal communities (Sovacool et al. 2018: 249).

Paradoxically, the adoption of generalised disaster risk reduction approaches and climate change adaptation measures can end up amplifying existing exclusionary pressures exerted on fishing families and other coastal dwellers. Coastal tourism and recreation, aquaculture, port facilities, export processing zones, as well as esplanades and seawalls to protect against erosion can, in some cases, pose greater threats to coastal dwellers' livelihoods and land tenure status than the risk of typhoons and tsunamis (Uson 2017). A possible way to investigate the diverse ways this plays out across the region is by adopting more disaggregated and grounded social science perspectives.

\section{STEPS TOWARDS DISAGGREGATION AND GROUNDING}

As our consideration of selected scholarly works in the social sciences has shown, human security in Southeast Asia requires more than general approaches and generic solutions. The latter does not reflect diverse realities on the ground and tend to aggregate individuals and communities. The consequence is to essentialise them. It has hopefully become clear that narrowly constructed framings of "risk" and "vulnerability" tend to ignore the contextual range of precariousness faced by marginalised communities across the region and simultaneously mask issues of power, politics and inequality. 
State-capital-development driven "territorialisation of risk" does more than describe objective risk; it aims to control people, space and resources, and to legitimate particular developments (O'Neill 2014: 173-205). Failure to acknowledge "the differences in interest that are part of the struggle to claim rights and resources within the very territories at risk" is to evacuate "the political" from the framing of risk (Rebotier 2012: 394). What we confront is a disciplining, silencing and trivialisation of the concerns of "unimagined communities." Whether it is remote upriver communities, subsistence fishermen, shifting cultivators or informal migrants, recognising and addressing their situations means doing more than solely relying on standardised responses to predetermined uncertainty and risk.

A small but growing body of work has begun to disaggregate and map the ways in which institutional forces and power-dynamics shape peoples' exposure to and understandings of risk, and how they respond differently (Rosario and Rigg 2019; Baird 2016; van Voorst 2016; Adams 2012; Knudsen 2012). Their approaches are invaluable for anyone concerned with decoding the politics of precariousness in Southeast Asia and responding appropriately. The fieldwork of Roanne van Voorst (2016) in particular highlights the efficacy of a detailed and grounded social science approach for mapping and revealing the factors and interests underlying precarious circumstances for risk-prone communities. She argues cogently that the actions of people in the face of risk are not wholly predicable. Risk handling behaviour cannot be explained simply by the risk itself, but instead by ostensibly disparate factors such as trust in state authorities or aid organisations and structural social inequalities. As detailed, if we are to draw greater attention to underlying socio-political conditions configuring circumstances of precariousness, we should take care in attending to the perceptual dimensions of risk and uncertainty based on identities, values and beliefs. Importantly, this involves detailing the political dimension of framing risk (in which the risk under scrutiny is subject to negotiation and contestation among political actors who have specific interests, goals and agendas).

\section{CONCLUSION}

Reconciling the ambition of human security with messy realities was never going to be straightforward. In an era of globalisation, there is a telling relationship between uncertainty, insecurity and violence; an unsettling human moiré patterned by overlapping local, national, regional and global forces, 
factors and interests. As mentioned at the beginning of our discussion, the many ways in which the politics of marginality and precariousness (human insecurities) play out across Southeast Asia are not readily understood or recognised. It is not possible to encapsulate the range of issues within a neat conceptual framework of human security, though as we have shown, it is important to emphasise the connections between issues of security, risk, uncertainty, marginality and trust.

In our examination of selected scholarship that focuses on processes of marginalisation and the construction of uncertainty, we moved in serial fashion from considering the emergence of insecurity, exploitation and dependence in early modernity to issues of risk, trust and respect in late modernity. Importantly, this drew attention to not only the consequences of marginalisation but the ways in which societal divisions, tensions and contradictions reproduce insecurities. It also foregrounded the agency of those rendered as "outsiders" and their responses to counter powerful forces of nation-state construction, economic development and globalisation.

When thinking about human insecurities in Southeast Asia and the ways in which to contextualise and address them, it is important to remember that the region is a vast and diverse entity of land and sea. The livelihoods and imaginaries of its people are also diverse and are undergoing rapid change. Reliance of its many upland, lowland, downriver, upriver, coastal and island peoples on the life-sustaining resources of the region's forests, rivers and seas is under increasing pressure. These realities defy and confuse in equal measure. Coming to terms with multiple human insecurities and their developmental, political and ethno-cultural diversity is a different proposition than generating standardised responses to predetermined problems. If we are to expand effectively the scope of "security" towards addressing the dayto-day inequities and lived insecurities experienced by many people across Southeast Asia (now and into the future), then gaining a better understanding of the interrelated conditioning forces and interests underlying them constitutes a significant step in that direction.

Our overview shows that there are specific concepts and approaches we can deploy in developing our understanding of the range of uncertainties, insecurities and risks currently exercising us. We attempted to re-situate human security not necessarily within a coherent theory but a "collage" of concepts relevant to the central preoccupations of the social sciences. On a conceptual level, this opens ways to understanding more fully the context of human insecurities for the communities and individuals who populate Southeast Asia. 


\section{NOTES}

* Paul J. Carnegie is Associate Professor of Politics and International Relations at the Institute of Asian Studies, Universiti Brunei Darussalam. His research specialises in human security, comparative democratisation and localised responses to militant extremism with a specific focus on Indonesia and Southeast Asia alongside the Asia Pacific more generally. Paul has published widely in his fields including the monograph The Road from Authoritarianism to Democratization in Indonesia (Palgrave Macmillan), the edited volume Human Insecurities in Southeast Asia (Springer) and outputs in leading international journals including Pacific Affairs, Australian Journal of Politics and History and Australian Journal of International Affairs. He is also a section editor for the Palgrave Handbook of Ethnicity. Paul has extensive applied research experience and networks having lived and worked previously in Australia, Brunei Darussalam, Egypt, Fiji and the United Arab Emirates.

** Victor T. King is Professor of Borneo Studies, Institute of Asian Studies, Universiti Brunei Darussalam; Emeritus Professor, School of Languages, Cultures and Societies, University of Leeds; formerly Executive Director of the White Rose East Asia Centre, Universities of Leeds and Sheffield. He has long-standing interests in the sociologyanthropology of Southeast Asia. Among his recent publications are UNESCO in Southeast Asia: World Heritage Sites in Comparative Perspective (ed., 2016), and coedited books on The Reconstruction of Southeast Asian Studies: Korea and Beyond (2013), Rethinking Asian Tourism: Culture, Encounters and Local Response (2014), Tourism and Monarchy in Southeast Asia (2016), Human Insecurities in Southeast Asia (2016), Borneo Studies in History, Society and Culture (2017), Tourism and Ethnodevelopment: Inclusion, Empowerment and Self-determination (2018), a fourvolume Routledge reader, Tourism in East and Southeast Asia (2018), Tourism in South-East Asia, reprint (2019), and Indigenous Amazonia: Regional Development and Territorial Dynamics (2020).

*** Magne Knudsen is Assistant Professor and Programme Leader of Sociology and Anthropology, Universiti Brunei Darussalam. His research broadly focuses on change and continuity in livelihood, family and community relations in coastal and upland regions of Southeast Asia. Magne holds a PhD (2010) in social anthropology from the Australian National University. Before coming to the Universiti Brunei Darussalam in 2015, he was a post-doctoral fellow at the National University of Singapore.

1 We would like to acknowledge and thank the three anonymous reviewers at the International Journal of Asia Pacific Studies (IJAPS) whose detailed comments and suggestions led to a fuller realisation of our thinking. As always, any limitations or omissions in this final version remain the responsibility of the authors.

2 Declaration of the Bali Concord II (ASEAN Concord II) at the 9th ASEAN Summit, Bali, October 2003 affirmed ASEAN's commitment to create "a people oriented" ASEAN Community (AC) based on three pillars, namely ASEAN Security Community (ASC), ASEAN Economic Community (AEC) and ASEAN Socio-Cultural Community (ASCC). In 2008, at the 13th ASEAN Summit, ASC was renamed ASEAN PoliticalSecurity Community (APSC). The blueprint for APSC tasks it with addressing transnational crimes, promote human rights and conduct post-conflict peacebuilding 
(ASEAN Secretariat 2009a: 5-13). ASCC is tasked to deal with illegal drugs, poverty and food security, healthcare issues alongside safeguarding against natural disasters, environmental degradation, and development inequality (ASEAN Secretariat 2009b: 6-24).

\section{REFERENCES}

Acharya, A. 2001. Human security: East versus West. International Journal 56 (3): 442460.

Adams, V. 2012. The other road to serfdom: Recovery by the market and the affect economy in New Orleans. Public Culture 24 (1): 185-216. https://doi.org/10.1215/089923631443601

ASEAN Secretariat. 2009a. ASEAN political-security community blueprint. Jakarta: ASEAN Secretariat.

2009b. ASEAN Socio-cultural community blueprint. Jakarta: ASEAN Secretariat.

Asia-Pacific HDR. 2006. Trade on human terms: Transforming trade for human development in Asia and the Pacific. UNDP Asia-Pacific Human Development Report, Delhi, Macmillan India Ltd. https://doi.org/10.18356/5847fd47-en

Austin, R. L. 2007. Effects of climate change and implications for land tenure: A community case study from Palawan Island, Philippines. Paper presented for the Center for International Environmental Law's contributions to the United Nations Climate Change Conference, Bali, 3-14 December.

Badan Pusat Statistik. 2012. Kewarganegaraan, suku bangsa, agama dan bahasa sehari-hari penduduk Indonesia. http://sp2010.bps.go.id/files/ebook/kewarganegaraan $\% 20$ penduduk\%20indonesia/index.html (accessed 20 January 2020).

Baird, I. G. 2016. Non-government organizations, villagers, political culture and the Lower Sesan 2 Dam in Northeastern Cambodia. Critical Asian Studies 48 (3): 257-277. https://doi.org/10.1080/14672715.2016.1157958

Bankoff, G. 1999. A history of poverty: The politics of natural disasters in the Philippines, 1985-95. The Pacific Review 12 (3): 381-420. https://doi.org/10 $.1080 / 09512749908719297$

Bauman, Z. 2000. Liquid modernity. Cambridge: Polity Press. 2003. Liquid love: On the frailty of human bonds. Cambridge: Polity Press. 2005. Liquid life. Cambridge: Polity Press. 2006a. Liquid fear. Cambridge: Polity Press. 2006b. Liquid times: Living in an age of uncertainty. Cambridge: Polity Press. 2011. Culture in a liquid modern world. Cambridge: Polity Press.

Bavinck, M. et al. 2017. The impact of coastal grabbing on community conservation A global reconnaissance. Maritime Studies 16 (8): 1-17.

Beck, U. 1992. Risk society: Towards a new modernity. London: Sage Publications.

Bertrand, J. 2004. Nationalism and ethnic conflict in Indonesia. Cambridge: Cambridge University Press.

Bhide, A. and Stevenson, H. 1992. Trust, uncertainty and profit. The Journal of SocioEconomics 21 (3): 191-208. https://doi.org/10.1016/1053-5357(92)90009-v 
Boholm, A. 1996. Risk perception and social anthropology: Critique of cultural theory. Ethnos: Journal of Anthropology 61 (1-2): 64-84. https://doi.org/10.1080/ 00141844.1996.9981528

Borras, S. M. and Franco, J. C. 2011. Political dynamics of land-grabbing in Southeast Asia: Understanding Europe's role. Amsterdam: Transnational Institute.

Buzan, B. 2004. A reductionist, idealistic notion that adds little analytical value. Security Dialogue 35 (3): 369-370. https://doi.org/10.1177/096701060403500326

Caballero-Anthony, M. 2004. Re-visioning human security in Southeast Asia. Asian Perspective 28 (3): 155-189.

2018. Negotiating governance on non-traditional security in Southeast Asia and beyond. New York: Columbia University Press.

Caballero-Anthony, M. and Cook, A. D. B. 2013. Non-traditional security in Asia: Issues, challenges and framework for action. Singapore: ISEAS.

Calvan, D. 2015. Land, property and tenurial rights in a changing coastal environment. Land Watch Asia, https://landportal.org/library/resources/land-property-andtenurial-rights-changing-coastal-environment (accessed 2 April 2020). https://doi .org/10.1093/oso/9780198854067.003.0002

Carnegie, P. J. 2015. Countering the (re-)production of militancy in Indonesia. Perspectives on Terrorism 9 (5) 15-26.

2017. State, security and militancy in Indonesia. In Palgrave handbook of global counterterrorism policy, eds. Romaniuk, S. N. et al., 733-747. New York: Palgrave Macmillan.

Carnegie, P. J., King, V. T. and Ibrahim, Z. (eds.). 2016. Human insecurities in Southeast Asia. Singapore: UBD-Institute of Asian Studies and Springer.

Chandler, D. 2008. Human security: The dog that didn't bark. Security Dialogue 39 (4): 427-439. https://doi.org/10.1177/0967010608094037

Chandler, D. and Hynek, N. (eds.). 2011. Critical perspectives on human security. London: Routledge.

ChinaPower. 2017. How much trade transits the South China Sea? https://chinapower.csis. org/much-trade-transits-south-china-sea/ (accessed 3 March 2020).

Chu, T-W. 2017. Riparians versus the state in Southeast Asia: Human security and hydropower struggles along the Mekong's Sesan Tributary. Asian Survey 57 (6): 1086-1109. https://doi.org/10.1525/as.2017.57.6.1086

Cohen P. J. et al. 2019. Securing a just space for the small-scale fisheries in the Blue Economy. Frontiers in Marine Science 6 (171): 1-8.

Commission on Human Security. 2003. Human security now. Washington, DC: Communications Development Incorporated.

Cooke, F. M. 1999. Forests, protest movements and the struggle over meaning and identity in Sarawak. Akademika 55: 99-132.

Davidson J. 2003. The politics of violence on an Indonesian periphery. Southeast Asian Research 11 (1): 59-89.

Douglas, M. 1992. Risk and blame: Essays in cultural theory. London and New York: Routledge.

Douglas, M. and Wildavsky, A. B. 1982. Risk and culture: An essay on the selection of technical and environmental dangers. Berkeley: University of California Press. 
Duffield, M. and Waddell, N. 2006. Securing humans in a dangerous world. International Politics 43 (1): 1-23.

Durkheim, E. 1893/1977. The division of labor in society, trans. Halls, W. D. New York: Free Press. . 1897/1951. Suicide: A study in sociology, trans. Spaulding, J. A. and Simpson, G. Glencoe, IL: The Free Press.

Eder, J. F. 2008. Migrants to the coasts: Livelihood, resource management, and global change in the Philippines. Belmont: Wadsworth Publishing Company.

Endicott, K. and Dentan, R. K. 2004. Into the mainstream or into the backwater? Malaysian assimilation of Orang Asli. In Civilizing the margins: Southeast Asian government policies for the development of minorities, ed. Duncan, C. R., 24-55. Ithaca and London: Cornell University Press.

Endres, K. W. and Six-Hohenbalken, M. 2014. Introduction to risks, rupture and uncertainties: Dealing with crisis in Asia's emerging economies. Cambridge Anthropology 32 (2): 42-48.

Fabinyi, M. 2010. The intensification of fishing and the rise of tourism: Competing coastal livelihoods in the Calamianes Islands, Philippines. Human Ecology 38 (3): 415-427. https://doi.org/10.1007/s10745-010-9329-Z

2018. Environmental fixes and historical trajectories of marine resource use in Southeast Asia. Geoforum 91: 87-96. https://doi.org/10.1016/j.geoforum .2018 .02 .033

Firth, R. 1966. Malay fishermen: Their peasant economy. London: Routledge \& Kegan Paul.

Forgacs, D., ed. 1988. The Antonio Gramsci reader: Selected writings 1916-1935. New York: Schocken Books.

Giddens, A. 1990. The consequences of modernity. Cambridge: Polity Press. 1991. Modernity and self-identity: Society in the late modern age. Cambridge: Polity Press.

Götz, N. 2015. 'Moral economy': Its conceptual and analytical prospects. Journal of Global Ethics 11 (1): 147-162. https://doi.org/10.1080/17449626.2015.1054556

Harris, O. 1996. The temporalities of tradition: Reflections on a changing anthropology. In Grasping the changing world: Anthropological concepts in a postmodern era, ed. Hubinger, V., 1-16. London and New York: Routledge.

Harvey, D. 2006. Neo-liberalism as creative destruction. Geografiska Annaler Series B: Human Geography 88 (2): 145-158. https://doi.org/10.1111/j.0435-3684.2006 $.00211 . \mathrm{x}$

Heine, J. and Thakur, R. (eds.). 2011. The dark side of globalization. New York: United Nations University Press.

Hijioka, Y. et al. 2014. Climate change 2014: Impacts, adaptation, and vulnerability. Part B: Regional aspects, Asia. Contribution of Working Group II to the Fifth Assessment Report of the Intergovernmental Panel on Climate Change, 1327-1370, Cambridge University, Cambridge. https://doi.org/10.1017/cbo9781107415416.020

Howe, B. 2013. The protection and promotion of human security in East Asia. Basingstoke: Palgrave.

2019. Human security, peacebuilding and the R2P in East Asia. Asian Journal of Peacebuilding 7 (2): 183-218. 
HSBC. 2012. Global research report. London: HSBC.

Human Rights Now. 2016. Sarawak, Malaysia: Infringement of the rights of indigenous people by continuous illegal logging practices. Tokyo: Human Rights Now.

Human Security Research Group. 2014. The decline in global violence: Evidence, explanation, and contestation - Human security report 2013. Vancouver: Human Security Press.

Hutton, W. and Giddens, A. (eds.). 2000. On the edge: Living with global capitalism. London: Jonathan Cape.

ILO. 2017. Global employment trends for youth 2017: Paths to a better working future. Geneva: ILO.

Iuchi, K. and Maly, E. 2016. Residential relocation processes in coastal areas: Tacloban City after Typhoon Yolanda. In Coming home after disaster: Multiple dimensions of housing recovery, eds. Sapat, A. and Esnard, A-M., 209-226. London and New York: Routledge.

Kaldor, M. 1999. New and old wars: Organized violence in a global era. Cambridge: Polity Press.

Kahn, J. S. (ed.). 1998. Southeast Asian identities: Culture and the politics of representation in Indonesia, Malaysia, Singapore, and Thailand. London and New York: I. B. Tauris Publishers and Singapore: Institute of Southeast Asia Studies.

Kelly, P. F. 1996. Blue revolution or red herring? Fish farming and development discourse in the Philippines. Asia Pacific Viewpoint 37 (1): 39-57. https://doi.org/10.1111/ apv.371003

Kerkvliet, B.J. 1977. The Huk rebellion: A study of peasant revolt in the Philippines. Berkeley and Los Angeles: University of California Press.

Khong, Y. F. 2001. Human security: A shotgun approach to alleviating human misery? Global Governance 7 (3): 231-236. https://doi.org/10.1163/19426720-00703003

King, V. T. 1978. Moral economy and peasant uprisings in South-East Asia. Cultures et Développement 10 (1): 123-149.

1980. Review of "The Huk Rebellion: A study of peasant revolt in the Philippines," by Benedict J. Kerkvliet. Modern Asian Studies 14 (1): 170-174. https://doi.org/10.1017/s0026749x00012257

1981. Review of "The rational peasant: The political economy of rural society in Vietnam," by Samuel L Popkin. Journal of Development Studies 17 (2): 249-251. https://doi.org/10.1525/ae.1981.8.1.02a00330

1993. Politik pembangunan: The political economy of rainforest exploitation and development in Sarawak, East Malaysia. In The political ecology of Southeast Asian forests: Transdisciplinary discourses (special issue), eds. Bryant, R. L., Rigg, J. and Stott, P., 253-244, Global Ecology and Biogeography Letters 3: 4-6. https://doi.org/10.2307/2997772

1995. Indigenous peoples and land rights in Sarawak, Malaysia: To be or not to be a Bumiputra. In Indigenous peoples of Asia, eds. Barnes, R. H., Gray, A. and Kingsbury, B., 289-305, 434-435, 478-480. Ann Arbor, MI: Association for Asian Studies.

2016. Review article: Conceptualising culture, identity and region: Recent reflections on Southeast Asia. Pertanika: Journal of Social Sciences and Humanities 2 (1): 25-42. 
Knudsen, M. 2009. This is our place: Fishing families and cosmopolitans on Negros Island, Philippines. PhD diss., Australian National University.

2012. Fishing families and cosmopolitans in conflict over land on a Philippine island. Journal of Southeast Asian Studies 43 (3): 478-499. https://doi.org/10.1017/ s0022463412000355

Krause, K. 2004. The key to a powerful agenda, if properly defined. Security Dialogue 35 (3): 367-368. https://doi.org/10.1177/096701060403500324

Law, L. S. et al. 2018. The identification of the factors related to household food insecurity among indigenous people (Orang Asli) in Peninsular Malaysia under traditional food systems. Nutrients 10 (10): 141-154. https://doi.org/10.3390/nu10101455

Liss, C. 2014. Security sector reform in Southeast Asia: The role of private security providers. In Security sector reform in Southeast Asia, ed. Heiduk F., 159-180. London: Palgrave Macmillan.

Marx, K. 1844/1968. Economic and philosophic manuscripts of 1844, trans. Mulligan, M. Moscow: Progress Publishers.

McCarthy, J. 2010. Processes of inclusion and adverse incorporation: Oil palm and agrarian change in Sumatra, Indonesia. Journal of Peasant Studies 37 (4): 821-850. https://doi.org/10.1080/03066150.2010.512460

Nishikawa, Y. 2010. Human security in Southeast Asia. London: Routledge.

Nixon, R. 2009. Unimagined communities: Developmental refugees, megadams and monumental modernity. New Formations 69: 62-80. https://doi.org/10.3898/ newf.69.03.2010

O’Neill, D. 2014. Playing risk: Chinese foreign direct investment in Cambodia. Contemporary Southeast Asia 36 (2): 173-205. https://doi.org/10.1355/cs36-2a

Paris, R. 2001. Human security: Paradigm shift or hot air? International Security 26 (2): 87-102. https://doi.org/10.1162/016228801753191141

2004. Still an inscrutable concept. Security Dialogue 35 (3): 370-372. https://doi.org/10.1177/096701060403500327

Popkin, S. L. 1979. The rational peasant: The political economy of rural society in Vietnam. Berkeley and Los Angeles: California University Press.

PPKKM. 2016. Buletin PPKKM, 2: 1-52.

Prakash, A. 2018. Boiling point. Finance and Development 55 (3): 22-26.

Rebotier. J. 2012. Vulnerability conditions and risk representations in Latin-America: Framing the territorializing urban risk. Global Environmental Change 22 (2): 391 398. https://doi.org/10.1016/j.gloenvcha.2011.12.002

Roberts, D. 2007. Human insecurity: Global structures of violence. London: Zed Books.

Rosario, T. C. and Rigg, J. 2019. Living in an age of precarity in 21 st century Asia. Journal of Contemporary Asia 49 (4): 517-527. https://doi.org/10.1080/00472336 .2019 .1581832

Roughneen, S. 2017. Southeast Asia is world's hotspot for land disputes. Nikkei Asian Review, 3 October.

Rutten, R. 2007. Losing face in Philippine labor confrontations: How shame may inhibit worker activism. In New perspectives in political ethnography, eds. Lauren, J., Mahler, M. and Auyero, J., 37-59. New York: Springer.

Scott, J. C. 1977. The moral economy of the peasant: Rebellion and subsistence in Southeast Asia. New Haven: Yale University Press. 
1985. Weapons of the weak: Everyday forms of peasant resistance. New Haven, CT: Yale University Press.

2013. Decoding subaltern politics: Ideology, disguise, and resistance in agrarian politics. New York and London: Routledge.

Scott, J. C. and Kerkvliet, B. J. 1977. How traditional patrons lose legitimacy: A theory with special reference to Southeast Asia. In Friends, followers and factions, eds. Schmidt, S., Guasti L. and Lande, C. Berkeley: University of California Press.

Silver, J. J. et al. 2015. Blue economy and competing discourses in international oceans governance. The Journal of Environment \& Development 24 (2): 135-160.

Sovacool, B. K., Tan-Mullins, M. and Abrahamse, W. 2018. Bloated bodies and broken bricks: Power, ecology, and inequality in the political economy of natural disaster recovery. World Development 110: 243-255. https://doi.org/10.1016/j. worlddev.2018.05.028

Standing, G. 2011. The precariat: The new dangerous class. London: Bloomsbury Academic.

2016. The corruption of capitalism: Why rentiers thrive and work does not pay. London: Biteback Publishing.

Stiglitz, J. 2002. Globalization and its discontents. New York: Norton.

Straumann, L. 2014. Money logging: On the trail of the Asian timber mafia. Basel: Bergli Books.

Survival International. 2013. Penan. https://www.survivalinternational.org/tribes/penan (accessed 9 April 2020).

Tajbakhsh, S. and Chenoy, A.M. 2006. Human security: Concepts and implications. London: Routledge.

Thompson, E.P. 1971. The moral economy of the English crowd in the eighteenth century. Past and Present 50 (1): 76-136. https://doi.org/10.1093/past/50.1.76 1963/2013. The making of the English working class. London: Penguin Books.

TMP Systems. 2017. Tenure and investment in Southeast Asia: Comparative analysis of key trends. Unpublished report, the Munden Project Ltd and Rights and Resources Initiative, 1-21.

ul Haq, M. 1995. Reflections on human development. Oxford: Oxford University Press.

UNDP. 1994. Human development report 1994: United Nations Development Programme. New York and Oxford: Oxford University Press. 2005. Human development report 2005: International cooperation at a crossroads. New York: UNDP.

United Nations. 2019. World population prospects 2019: Highlights. New York: Department of Economic and Social Affairs.

Uson, M. A. M. 2017. Natural disasters and land grabs: The politics of their intersection in the Philippines following super typhoon Haiyan. Canadian Journal of Development Studies 38 (3): 414-430. https://doi.org/10.1080/02255189.2017.1308316

Watson, S. and Moran, A. (eds.). 2005. Trust, risk and uncertainty. Basingstoke: Palgrave Macmillan.

Wertheim, W. F. 1965. Society as a composite of conflicting value systems. In East-West parallels: Sociological approaches to modern Asia, ed. Wertheim, W. F., 23-38. Chicago: Quadrangle Books. 
1974. Evolution and revolution: The rising waves of emancipation. Harmondsworth: Penguin Books.

Wessel, I. and Wimhofer, G. (eds.). 2001. Violence in Indonesia. Hamburg: Abera Publishing House.

Wilson, I. 2012. Testing the boundaries of the state: Gangs, militias, vigilantes and violent entrepreneurs in Southeast Asia. In Routledge handbook of Southeast Asian politics, ed. Robison, R., 288-301. New York and London: Routledge.

WHO. 2014. Preventing suicide: A global imperative. WHO. https://www.who.int/mental _health/suicide-prevention/world_report_2014/en/ (accessed 3 March 2020). 2020a. Mental health: Suicide data. WHO Media Centre. https://www.who.int/ mental_health/prevention/suicide/suicideprevent/en/ (accessed 3 March 2020) $2020 \bar{b}$. Mental health: Suicide and suicide prevention in Asia. WHO Media Centre. https://www.who.int/mental_health/publications/suicide_prevention_asia/ en/ (accessed 3 March 2020).

van Voorst, R. 2016. Natural hazards, risk and vulnerability: Floods and slum life in Indonesia. New York: Routledge.

Yee, D. K. P. 2017. Constructing reconstruction, territorializing risk: Imposing 'no-build zones' in post-disaster reconstruction in Tacloban City, Philippines. Critical Asian Studies 50 (1): 103-121. https://doi.org/10.1080/14672715.2017.1407663

Zinn, J. O. (ed.). 2008. Social theories of risk and uncertainty: An introduction. Oxford: Blackwell Publishing. 